DOI: https://doi.org/10.32839/2304-5809/2020-4-80-138

UDC 371.356 .542

Shevchenko Maryna, Poprotska Daria

Donbass State Teacher Training University

\title{
WAYS OF SOLVING OF SEMANTIC PROBLEMS OF TRANSLATION
}

Summary. The article deals with the main features and problems of translating of lexical units from the foreign language. The author emphasizes the importance of this process, and also points out the difficulties that can arise during the translation. It is pointed out that the personality of translator must be comprehensively developed and he should have a high level of intelligence. The main approaches of the texts translating are considered, they are: cognitive, global and special approaches. The author also defines the main task of translation - the transfering of the basic idea and meaning from one language into another, while saving all the linguistic and cultural features of the text. Translators - like all professionals, must undergo continuous training and refinement of their skills through experience, self-examination and self-correction. Their "production" potential should not always be measured in terms of translated pages or words, but rather, to evaluate the quality of the finished work, which requires a set of standards and rules. The main task of translation is to transfer the basic idea and meaning from a foreign language to the native language, taking into account all linguistic and cultural features. To solve translation problems, the translator must use all his or her mind, creativity, intuition, and ingenuity. In this matter, the overall level of the translator's intelligence and his / her professional training is very important. An analysis of translation problems with certain linguistic units may be a prospect for further research. It should also be noted that translators must constantly make the choice of a translation strategy in each paragraph to decide which ones are most useful for correctly communicating the ideas of a particular text. This means adapting the most effective strategies and methods to the requirements of the text, rather than applying only one specific technique to all types of text. Another important aspect is that translators should always retain the style, essence, meaning of the source text, as well as its format: paragraphs, indentations of the table, references to sources. By adhering to all these forms, we will maximize the approximation of the original text.

Keywords: translation, transformation, efficiency, native language, culture.

Шевченко М.Ю., Попроцька Д.Т. Донбаський державний педагогічний університет

\section{ШЛЯХИ ВИРІШЕННЯ СЕМАНТИЧНИХ ПРОБЛЕМ ПЕРЕКЛАДУ}

Анотація. У статті аналізуються основні особливості та проблеми перекладу лексичних одиниць з іноземної мови. Автор підкреслюе важливість цього процесу, а також вказуе на труднощі, які можуть виникнути при перекладі. Окремо відзначено, що особистість перекладача повинна бути всебічно розвинена і мати високий загальний інтелект. Розглянуто основні підходи до перекладу текстів: когнітивний, глобальний та спеціальні підходи. Автор також визначає основну задачу перекладу - передача основної ідеї та сенсу з одніеї мови на іншу, при цьому зберігаючи всі лінгвістичні та культурні особливості тексту. Якими б не були труднощі під час процесу перекладу, слід зосередитись на сутності повідомлення та вірності значенню вихідного тексту, що передаеться мовою перекладу. Переклад складається з відтворення найближчого еквівалента повідомлення від джерела до мови перекладу з усіма семантичними та стилістичними аспектами. Значною мірою якість перекладу буде залежати від особистих якостей перекладача, тобто від його знань, навичок, рівня навчання, культурного досвіду, досвіду та навіть настрою. Вчені виділяють деякі істотні характеристики, якими повинен володіти будь-який професійний перекладач: вміння розпізнавати тексти іноземною мовою, знання та чутливість до мови (як рідної, так і іноземної), компетентність усному та писемному мові. Пошук дилем - це тривалий процес у роботі перекладача. Сюди входить боротьба 3 такими проблемними явищами, як: мовний чи культурний «переклад», здатність керувати недоліками та перевагами перекладу, вирішенням лексичної неоднозначності тощо. Ці проблеми вирішуються за допомогою використання різних механізмів, таких як пояснювальні записки, адаптація, еквівалентність, парафрраза, аналогія тощо. Перекладачі також повинні розуміти, що сенс сказаного - це не просто слова. Тому адекватне декодування та перекодування фігур, таблиць та діаграм; стандартизовані терміни, абревіатури, метонімія, назви топологій тощо - це елементи, яким слід приділяти особливу увагу, щоб максимально наблизити текст для перекладу, наприклад: мета тексту, його читацькіbстандарти, повідомлення, яке несе текст, тип дискурсу, перекладач та читач.

Ключові слова: переклад, трансформація, ефективність, рідний мова, культура.

$\mathrm{F}$ Tormulation of the problem. Translation activities have several specific goals, depending on the specific situation and field of activity. The main purpose of translation is to serve as an intercultural multilingual means of communication between peoples. In the last few decades, this activity has evolved in the context of increased international trade, increased migration, globalization, recognition of linguistic minorities and the expansion of the media. In this regard, the translator plays an important role as a multilingual transmitter of culture and information, who tries to interpret the concepts and content of the various utterances as accurately as possible.

The relevance of the study is undeniable. The consequences of incorrect translations can be catastrophic, especially if done by non-professionals, and mistakes made in the performance of these activities can be fatal. This is especially true in cases of serious misconduct in the fields of medicine, legal matters or technology. 
It is quite obvious that poor translation can not only lead to minor confusion, but can also be a matter of life and death. Therefore, the purpose of translator training lies not only in the acquisition of orientation skills in languages, translation and its technologies, but also in specific areas of knowledge and, equally importantly, in professional ethics.

The subject of the study is the problem of translation from a foreign language into a native language.

The object of the research is the process of translation of lexical units from foreign into their native language.

The purpose of the study is to analyze the features of the translation process, its problems and ways of solving them.

Analysis of research and publications. Many domestic and foreign scholars have considered the laws, principles, and problems of the translation process, including: V. Karaban, J. Retzker, V. Komissar, P. Newmark, R. Bell, and others.

Most translation practice theorists agree that translation is understood as a process of transmitting information from a foreign language into their native language. However, market demands are increasingly demanding that translators translate texts into a language other than their native language. P. Newmark calls this phenomenon "service translation». The scientist also stated: «I assume that most translators learn to translate into their usual language of use, as this is the only way they can translate naturally, accurately and with maximum efficiency. Thus, most translators make translations based on their native language» [3, p. 25].

This fact makes the translation process more difficult, sometimes leading to mediocre translations, which no doubt need to be revised and edited before being published.

Main material. If translation is a discursive operation between language and thought, we must recognize that in the art or skill of translation, we will inevitably face numerous obstacles.

D. Delisle emphasizes how thin the translation process is:

"Translation is hard work that, from time to time, leads you to despair, but at the same time it constantly enriches us with new skills and knowledge» [1, p. 101].

There are many obstacles that can arise during the translation process, regardless of the nature of the text we are working with. The first problem is related to the ability to read and understand the original language. Once the interpreter has dealt with this obstacle, further translation difficulties will have a semantic and cultural character [5, p. 15].

Very often we come across such a phenomenon as "linguistic non-translation", which includes related and similar words, tracing books and its forms, standardized terms, neologisms, aphorisms, etc.

Another obstacle for the translator is the "cultural impossibility of translation", which includes idioms, expressions, sayings, jokes, puns, etc. Care should be taken with regard to such words or expressions in order to avoid incorrectness and abuse of language [2, p. 35].

Similarly, we often come across special terms for which even a dictionary or native speaker cannot provide a solution for conveying the exact meaning.
In such cases, it should be noted that one of the best qualities of a translator is "contextualizing intuition", that is, the ability to quickly find the closest interpretation of the meaning of an unknown element in its context.

Whatever the difficulties during the translation process, it should be focused on the essence of the message and the fidelity to the value of the source text transmitted in the language of the translation. According to E. Nida and C. Taber: "Translation consists of reproducing the closest equivalent of the message from the source to the language of translation with all the semantic and stylistic aspects" [4, p. 68].

To a large extent, the quality of the translation will depend on the personal qualities of the translator, ie on his knowledge, skills, level of study, cultural background, experience and even mood. M. Newmark highlights some of the essential characteristics that any professional translator should have: the ability to recognize texts in a foreign language, knowledge and sensitivity to the language (both native and foreign), competence in oral and written language [3, p. 23].

In addition, M. Trikas refers to intuition or common sense as the most important of all the qualities of a translator. In other words, in the process of translation it is very important to use a combination of intelligence, sensitivity and intuition: «The translation process is a complex mechanism of choice of approaches in which all intellectual abilities, skills and intuition must be used» [5, p. 98].

There are several approaches to improving translation skills:

1. A cognitive approach is applied to the process of transferring ideas from one language to another, which obviously means much more than a simple model of reproduction. In the preparatory phase of translation, cognition in the form of self-awareness and self-confidence plays a very important role, since this period involves conscious mental activity in which problems with translation are identified and analyzed [2, p. 14].

It should be noted that, from a psychological and social point of view, an interpreter who is an employee of an intellectual field with special professional characteristics will be more successful if special attention is paid to his socio-affective development. In this case, he or she may be better prepared to work with people, and to achieve a higher level of tolerance, exhibiting self-criticism and sensitivity.

2. Global approach. Considering the main approaches to translation, it should be noted that the most famous translation theorists agree on the following aspects:

First, there are certain rules for understanding and interpreting texts, which mean managing the principles of special approaches to different types of texts, taking into account their individual characteristics. This competence includes reading comprehension and interpreting messages (encoding and decoding).

Secondly, reformulation is also an important aspect. This means applying different strategies to the process of message restitution (recoding), by selecting the appropriate methods and techniques. The most commonly used techniques for conveying the main idea contained in translation units that a translator can use are: transferring a cultural or 
functional equivalent, synonymy, transposition, modulation; reducing and expanding the meaning of a word, as well as enhancing its meaning [3, p. 16].

These elements form the essence of translation and are part of the translator's competence. They should be most clearly marked when preparing future translators. Different types of literature should also be used for these purposes: concurrent texts, monolingual and bilingual dictionaries, encyclopedias, terminology databases, and other sources.

Thirdly, translation theorists attach great importance to the evaluation of the result, that is, to prove the meaning of the translated text and its original. In this case, the translator has the ability to adequately evaluate the translation, mark its shortcomings, demonstrating the ability to self-correct. Viewing the result of a failed translation will always lead to a higher quality final translation.

3. Special approaches. Most translation theorists believe that specific approaches to text translation are generally similar. On the one hand, one or more translation approaches or models must be used. On the other hand, there is always a way to approach the text of the target language, regardless of whether the translator chooses certain types of models: author-oriented, structurally-oriented, text-oriented, cognitive or reader-oriented. Depending on the situation, translators will use a particular model, but many are prone to eclectic integration of all models.

Translators should understand that misinterpretation of the text significantly reduces the quality of the translation. Therefore, reading comprehension strategies for translation (word selection, translation difficulty, contextualization of lexical elements, adaptation, analysis, etc.) should be used.

Finding dilemmas is an ongoing process in translator work. This includes dealing with such problematic phenomena as: linguistic or cultural "non-translation", the ability to manage the disadvantages and benefits of translation, the solution of lexical ambiguity, and so on. These problems are solved through the use of various mechanisms, such as explanatory notes, adaptation, equivalence, paraphrase, analogy, etc.

Translators should also understand that the meaning of what is said is not just words. Therefore, adequate decoding and re-encoding of figures, tables and diagrams; standardized terms, acro- nyms, metonymy, place names, etc. are elements that should be given particular attention.to some significant anchor points to maximize the approximation of the text to be translated, for example: the purpose of the text, its readership, the specific standards used by the author, the message that carries the text, the type of discourse, the translator, and the reader.

Another important aspect is pre-editing the source text to identify possible inaccuracies on the one hand, and post-editing the translated text to test the use of the most appropriate syntactic, semantic units, on the other.

Among the formal questions, translators must know and control the sound effect and cadence of the translated text to avoid incorrect phonetic combinations and tracing in the original language.

It should also be noted that translators must constantly make the choice of a translation strategy in each paragraph to decide which ones are most useful for correctly communicating the ideas of a particular text. This means adapting the most effective strategies and methods to the requirements of the text, rather than applying only one specific technique to all types of text.

Another important aspect is that translators should always retain the style, essence, meaning of the source text, as well as its format: paragraphs, indentations of the table, references to sources. By adhering to all these forms, we will maximize the approximation of the original text.

Conclusion. Translators - like all professionals, must undergo continuous training and refinement of their skills through experience, self-examination and self-correction. Their "production" potential should not always be measured in terms of translated pages or words, but rather, to evaluate the quality of the finished work, which requires a set of standards and rules. The main task of translation is to transfer the basic idea and meaning from a foreign language to the native language, taking into account all linguistic and cultural features.

To solve translation problems, the translator must use all his or her mind, creativity, intuition, and ingenuity. In this matter, the overall level of the translator's intelligence and his / her professional training is very important. An analysis of translation problems with certain linguistic units may be a prospect for further research.

\section{References:}

1. Gumboldt, V. (1984). Izbrannye trudy po yazykoznaniyu [Selected works in linguistics]. Moscow: Progress. (in Russian)

2. Hrolenko, A.T., \& Bondaletov, V.D. (2006). Teoriya yazyka: Uchebnoe posobiye [The theory of language]. Moscow: Flinta. (in Russian)

3. Grimes Joseph E. (1972). The Thread of Discourse. New York: The A-book.

4. Langacker Ronald. Discourse in Cognitive Grammar (2005). Washington: Freetime.

5. Chafe, W. Discourse, consciousness and time : The flow and displacement of conscious experience in speaking and writing (1994). Chicago: University of Chicago Press. 